\title{
Lectores y espectadores: Beatriz Sarlo crítica de cine*
}

Readers and Spectators: Beatriz Sarlo, Film Critic

David Oubiña a

Universidad de Buenos Aires y Conicet, Argentina

doubinia@retina.ar

ORCID: https://orcid.org/0000-0002-4770-5476

DOI: https://doi.org/10.11144/Javeriana.cl24.lebc

Recibido: 10 Abril 2017

Aceptado: 08 Junio 2017

Publicado: 28 Diciembre 2020

\section{Resumen:}

Las intervenciones de Beatriz Sarlo a propósito de cuestiones cinematográficas continúan y expanden sus preocupaciones en tanto que crítica literaria. Sin duda, se aproxima al cine con las herramientas que aprendió en la literatura, pero, a diferencia de lo que suele suceder con muchos críticos culturales, no piensa los films como un objeto derivado. Más bien, al contrario: cuando escribe sobre Chantal Akerman, sobre Rainer Fassbinder, sobre Claude Lanzmann o sobre Raya Martin, despliega una erudición cinéfila que le permite amplificar su pensamiento literario y proyectarlo como una compleja teoría política de la cultura.

Palabras clave: cine de ideas, cine e historia, cultura elevada y cultura popular, intelectuales y medios audiovisuales, memoria y olvido.

\begin{abstract}
:
Beatriz Sarlo's essays on cinema continue and develop her interests as a literary critic. She obviously approaches cinema with the instruments she acquired in literature; but despite what usually happens with many cultural critics, she doesn't consider films as subsidiary objects. On the contrary: When she writes about Chantal Akerman, about Rainer Fassbinder, about Claude Lanzmann or about Raya Martin, she displays a cinephile erudition that heightens her literary ideas in order to project them as a complex political theory of culture.
\end{abstract}

Keywords: cinema of ideas, cinema and history, high culture and popular culture, intellectuals and audiovisual media, memory and oblivion.

\section{La matriz de la literatura}

Beatriz Sarlo elige el título "Un escrito irresponsable” para un ensayo sobre el guion cinematográfico. Esa irresponsabilidad alude de manera extensiva al género de la escritura para el cine (porque el guion es un programa del film futuro y, entonces, carece del momento del estilo), pero también remite, en un sentido más singular, al propio texto de la autora (ya que comienza por admitir su escasa experiencia como guionista y, por lo tanto, sitúa sus comentarios en una dimensión ajena a la de los especialistas) (“Un escrito” 135). Desde siempre, la industria del cine ha considerado al guionista como un extranjero en esa fábrica de los sueños: "A schmuck with an Underwood", tal como dijo brutalmente uno de los hermanos Warner, porque permanece demasiado aferrado al poder simbólico de las palabras que, finalmente, no son la materia audiovisual de la que están hechos los films. Sarlo, crítica literaria, se adjudica a sí misma esa forma de extranjería irresponsable cuando escribe para o sobre cine: como una inquilina que se instalara provisoriamente (clandestinamente) en el departamento de las imágenes con su equipaje de teoría literaria.

Lo ha dicho en muchas oportunidades: lee todo según la matriz interpretativa que aprendió en la literatura. Eso es cierto, pero no es toda la verdad. Las intervenciones de Sarlo a propósito de cuestiones cinematográficas continúan y expanden sus preocupaciones en tanto que crítica literaria, pero, a la vez, habría que decir que esos trabajos poseen un perfil propio, autónomo y definido: curiosamente, al no ser una especialista en cine,

Notas de autor

\footnotetext{
${ }^{\mathrm{a}}$ Autor de correspondencia. Correo electrónico: doubinia@retina.ar
} 
eso confiere a sus reflexiones una notable libertad para formular hipótesis, un "irresponsable" dinamismo para poner a prueba desarrollos conceptuales y una audacia experimental para incursionar por territorios estéticos poco transitados. A pesar de eso, no se le ha prestado demasiada atención a esta faceta de su labor ensayística, como si se tratara de un desvío o como si fueran los textos de una aficionada. Sin duda, Sarlo se aproxima al cine con el capital que ha acumulado en la literatura, pero, a diferencia de lo que suele suceder con muchos críticos culturales (formados en las Letras), no piensa los films como un objeto derivado, como novelas en imágenes, como un discurso sin entidad propia que solo sirve para ilustrar conceptos que provienen de otras disciplinas. Más bien, al contrario: cuando escribe sobre Chantal Akerman, sobre Rainer Fassbinder, sobre Claude Lanzmann o sobre Raya Martin, despliega su erudición cinéfila y piensa las películas en los términos concretos de sus estrategias audiovisuales.

Como docente y como investigadora, la literatura argentina es su campo de trabajo. Hay allí una misión pedagógica y, aunque Sarlo siempre ha evitado la figura del experto académico, no puede negarse a dar respuesta: expedirse sobre el canon, confrontar con la tradición literaria, realizar intervenciones fuertes, descubrir escritores nuevos, producir lecturas originales. Esto no suele suceder en el caso de sus ensayos sobre cine: no hay en ellos un carácter ineludible y, por lo tanto, puede elegir sus intervenciones de manera no sistemática, allí donde se siente interpelada. Al carecer de un compromiso profesional, no está obligada a construir un panorama abarcador sobre el cine argentino. Y así como siente la necesidad de leer a los jóvenes escritores, en cambio no ha publicado mucho sobre el nuevo cine. Justamente porque ya hay otros que escriben sobre eso. En las ocasiones en que ha reflexionado sobre el fenómeno de los films recientes, ha sido para producir una intervención crítica: para romper el frente de celebración unánime a propósito de ciertos films (es el caso de Relatos salvajes o de Los rubios) y abrir el debate. ${ }^{1}$

\section{Cine de ideas}

En dos textos tempranos para la revista Los Libros, Sarlo se ocupa del cine argentino de ese momento. Significativamente, ambos artículos giran alrededor de Leonardo Favio; pero, mientras uno de ellos incluye a Juan Moreira como parte del "renacimiento" del cine argentino entre 1973 y 1974 (La Patagonia rebelde, Quebracho, La Mary, Los siete locos, Boquitas pintadas, La tregua), el otro se concentra especialmente en Nazareno Cruz y el lobo. Se trata de dos ensayos, influenciados por la lectura de Gramsci, que intentan contribuir a la elaboración de una teoría sobre el cine y la cultura popular. Para Sarlo, lo curioso del panorama renovador de comienzos de la década radica en que son películas pertenecientes al circuito comercial las que han despertado el interés del público por temas que se vinculan con "la realidad nacional". Sin duda, este interés masivo (que acompaña el proceso político puesto en marcha por el retorno al poder del peronismo) no carece de aspectos negativos: La Mary aprovecha la identificación fácil del público con los héroes populares del folletín sentimental, Torre Nilsson no entendió nada en la novela de Arlt ni en la de Puig y La tregua es una película conformista (cuya crítica a la alienación se circunscribe a las relaciones entre individuos, mientras deja intactos los conflictos reales que producen esas relaciones). La Patagonia rebelde y Quebracho, en cambio, rescatan para la pantalla las luchas de los trabajadores; pero es, sobre todo, en el cine de Favio donde se insinúa el camino de un proyecto auténticamente popular.

Dentro de un cine argentino adocenado y poco imaginativo, Favio es indudablemente el único realizador sobre el que vale la pena escribir. Si sus tres primeras películas habían sido obras de un "director para cineclubs", con Juan Moreira se convirtió en un cineasta inmensamente exitoso. Nazareno Cruz y el lobo fue incluso más taquillera (3\#00\#00 espectadores), pero le valió críticas y burlas por su estética kitsch, por su barroquismo ingenuo, por su esquematismo exagerado. Los análisis de Sarlo a propósito de estas películas son notables, porque logran escapar a los lugares comunes: ya sea el entusiasmo delirante de los fanáticos o el desprecio condescendiente de la crítica progresista. Sus artículos indagan sobre los films con respeto y los 
analizan en serio, como objetos culturales valiosos (más allá del gusto personal) que deben ser deconstruidos para averiguar qué quieren comunicar. Dice Sarlo: "Favio es el director argentino que se hace cargo de temas, situaciones, mitos que, en nuestro país, están relacionados en profundidad con las experiencias actuales o la historia de amplios sectores populares" ("Sobre Nazareno" 24).

Sarlo ve a Favio como un cineasta gramsciano. O más bien: ve sus películas como un escenario donde es posible aplicar las ideas de Gramsci a propósito de la cultura popular. Hay en ese cine una reelaboración del folletín, de los mitos populares y del costumbrismo dentro de un relato no exento de contradicciones, pero que, claramente, practica una defensa de los subalternos según la perspectiva (y el límite) populista de un director alineado con el peronismo. Afirma Sarlo sobre Juan Moreira:

Desde el punto de vista político, la película condenaba la justicia oligárquica de un período y al mismo tiempo convertía al perseguido por esa justicia en colaborador y guardaespaldas de un político rural terrateniente. La contradicción atravesaba la obra de Favio por zonas por donde también atraviesa a la ideología populista: exaltación del marginado y solución paternalista de sus conflictos. (“Cine argentino” 12)

Los films del realizador pertenecen a esa capa de la cultura popular donde se impugna la perspectiva de las clases dominantes a partir de productos que - aun cuando están atravesados por elementos ideológicos - logran construir un sistema alternativo precario y contradictorio. Favio toma partido por el bandido injustamente perseguido frente al peón trabajador y elige el mito rural del lobizón frente a las narraciones hagiográficas. Hay ahí un principio de autonomía. Es insuficiente, sin duda, pero no debería ser desestimado en la propuesta de un cambio revolucionario.

A diferencia de La hora de los hornos, que ha pasado mal de la clandestinidad al circuito comercial y no ha cumplido con su función propagandística (ya que no ha conseguido captar el interés de aquellos sectores a los que pretende interpelar), Juan Moreira es cine de masas que se mantiene dentro de los límites del populismo, pero se arraiga en la tradición de una cultura popular y nacional. ${ }^{2}$ De todos modos, y más allá de sus hallazgos de crítica ideológica, en estos textos para Los Libros la perspectiva específicamente cinematográfica resulta aún tímida e insegura. Sarlo prefiere usar las películas como un campo de debate donde expandir (por otros medios o, más bien, en otros medios) las discusiones que tienen lugar en las páginas vecinas de la revista. Algo similar ocurre con su primera nota sobre cine para Punto de Vista: una reseña de Julia, film menor de Fred Zinnemann, en la que el análisis de la trama tiende a confundirse con la biografía de Lillian Hellman y cuyo mayor interés radica en la trasposición indirecta del macartismo al contexto argentino luego del golpe (ese "tiempo de canallas"). ${ }^{3}$

Pero en seguida, en julio de 1978, en plena dictadura militar, Sarlo publica un artículo sobre un ciclo Fassbinder en el Instituto Goethe: aunque no hay ninguna referencia al contexto político, la elección del director y el tono del texto deberían leerse como un acto de resistencia. Se trata de una nota introductoria (Fassbinder era casi desconocido más allá del pequeño público del Goethe, de la Cinemateca o de la sala Leopoldo Lugones) y Sarlo entiende que es necesario presentarlo ante "el abstinente público argentino" ("Fassbinder" 29). Por eso, prolijamente, empieza por los datos biográficos y por un repaso de las influencias del cineasta, antes de analizar las líneas principales que pueden observarse en las películas exhibidas durante la retrospectiva. El artículo carece de la densidad y la sofisticación que pueden encontrarse en textos posteriores (sobre Lanzmann o sobre Tarkovsky, por ejemplo); sin embargo, es un texto importante porque aquí Sarlo encuentra un director con quien comparte cierta concepción estética y unas películas en las que puede comenzar a desarrollar sus propias ideas sobre el cine.

En Fassbinder es posible reconocer una tradición de crítica brechtiana y una conciencia clara sobre la función social del arte, pero, también, una potencia formal deslumbrante. Sarlo conoce a Brecht, así como conoce la lectura que Barthes ha hecho sobre Brecht. ${ }^{4}$ El mercader de las cuatro estaciones o Las amargas lágrimas de Petra von Kant retoman temas muy transitados por el cine y la literatura, pero esas situaciones son 
el espacio argumental que, trabajado con los motivos que unen o separan a hombres y mujeres, es ocupado en realidad (y esto lo percibe incluso la lectura más superficial) por las verdaderas situaciones: sociales, económicas, propias de la moral, la ideología y las conductas colectivas. (Sarlo, "Fassbinder" 29)

Lo típico aparece dramatizado como situación extrema, desbordada, siempre derrapando hacia la demencia. He ahí la pedagogía estético-política de Fassbinder. Como si cada film intentara responder la misma pregunta: ¿qué sucede cuando un individuo es empujado hasta un límite (de explotación, de racismo, de miseria, de crueldad) donde la escena de ficción permite revelar nítidamente el funcionamiento de los mecanismos sociales?

En todo caso, el cine de Fassbinder no es el de los Taviani. Sarlo recurre aquí a la comparación con Padre padrone, cuyo estreno en Buenos Aires había causado gran impacto y que había sido reseñado en el número anterior de Punto de Vista. Para la revista, el film de los Taviani pertenece al género de los relatos edificantes, en los que los héroes triunfan sobre las determinaciones y logran desafiar los límites de su destino: en este caso, un bildungsroman sobre un pastor analfabeto que se convierte en profesor universitario. Padrepadrone podría ser el cuento de un "Kaspar Hauser triunfal" o una "versión exasperada de Recuerdos de provincia" ("Punto de Vista señala" 27). La reseña no quiere ser injusta con una película que juzga notable en varios aspectos; por eso rescata la hipótesis central que subyace a las imágenes: la opresión siempre genera resistencia. Aun así, la rebelión contra el padre solo se define cuando el protagonista se convierte en propietario. Basándose en la autobiografía de Gavino Ledda, los Taviani narran una historia real, pero "paradójicamente, en el film, la historia real es la que no se cuenta: la historia de los jóvenes campesinos del sur de Italia que emigran a los países industrializados de Europa. De campesinos a obreros industriales: esa historia parece más verdadera" (27). Las contradicciones internas del relato se manifiestan en el propio título del film, en esa homologación entre el padre y el patrón. Cuando se entregan al estudio casi antropológico de esa sociedad campesina opresiva y patriarcal, los Taviani consiguen sus momentos más lúcidos; pero cuando se inclinan por la historia singular del joven, acentuando sus rasgos psicologistas, la película se asoma peligrosamente al moralismo y a la fábula. Para Fassbinder, en cambio, no hay psicología que escape a un condicionamiento colectivo. Es lo que sucede con la úlcera mortal del inmigrante marroquí, en La angustia corroe el alma, o con el ataque de locura del obrero, en Solo quiero que me amen: son deícticos que apuntan hacia un más allá de la representación. La identificación con los personajes nunca es completa porque el director impone una distancia reflexiva y no permite olvidar que ellos son agentes de un conflicto que se decide invariablemente en otra dimensión. Sarlo dice que es "un cine de ideas", pero, obviamente, no porque las imágenes sean mero sostén de un discurso que sería anterior y exterior, sino porque ellas mismas dramatizan una forma de pensamiento audiovisual sobre la pantalla.

Ese interés por la forma cinematográfica de un concepto es un descubrimiento que Sarlo hace con Fassbinder y que desarrollará en textos posteriores. Para decirlo en los términos de Deleuze: ¿qué es tener una idea en cine? Por ejemplo: el de Raya Martin es un "cine conceptual". Su película Autohystoria no narra la memoria del movimiento independentista de los katipuneros filipinos, sino que muestra el pasado como si fuera un presente. No hay anécdota, no hay reconstrucción, no hay representación, no hay verosímil; al aplanar el mundo pretérito sobre el paisaje actual (al hacer de la actualidad una función de lo pretérito), Martin consigue una síntesis descarnada que se saltea los hechos históricos para mostrar, más bien, una perspectiva crítica sobre ellos. El cineasta

deliberadamente muestra el pasado como relato inconcluso que sigue repitiéndose: el pasado sucede hoy, como afirma Autohystoria y el film no quiere hacer pedagogía de masas (para eso hay otros medios probablemente más adecuados que el buen cine), sino sostener que el pasado sigue abierto. (Sarlo, "Un cine conceptual" 38)

Y de la misma manera, la originalidad de Godard en las Historia(s) del cine no está en sus hipótesis que son, al fin y al cabo, muy conocidas (el doble comienzo según Griffith o Eisenstein, el cine no supo ver los campos de concentración, Hitchcock es el más grande creador de formas, el neorrealismo italiano fue el 
primer movimiento moderno), sino en el método de conceptualización audiovisual que pone en juego. La Historia de Godard procede por corsi e ricorsi de motivos puramente cinematográficos: ese extenso roman fleuve que es el film se mueve por choques escandalosos, por atracciones brutales, por derivaciones impensadas, por sobreimpresiones sugerentes, por recontextualizaciones reveladoras. Godard dice "una forma que piensa / un pensamiento que forma”. Sarlo insinúa que hay allí un modo de razonamiento y de argumentación completamente audiovisual porque el montaje pone en escena una dimensión teórica de la imagen (en la imagen) (véase "La originalidad").

La repetición de un gesto, la coincidencia de una fecha, una afinidad cromática, un juego de palabras: Godard encuentra nexos inesperados entre las imágenes e inventa un modo de narrar. A veces es un encastre perfecto, a veces un salto mortal, a veces una paradoja. Dice en Historia(s) del cine: "Porque Auschwitz pudo ser filmada en colores, tres o cuatro años después, pudimos ver la felicidad de Elizabeth Taylor en la pantalla". Godard invade la historia del cine. Como un conquistador que ocupa una ciudadela sitiada: invade la historia del cine (toma de rehén una impresionante cantidad de fragmentos provenientes de películas de todos los tiempos), pero la desarma y la rearma para producir una interpretación que no es deudora de ningún discurso exterior, sino que está construida sobre una combinación de imágenes que han aprendido a observarse entre sí. Bajo otra modalidad, Sarlo reencuentra esta tensión entre formas y conceptos durante "La noche de las cámaras despiertas". Este episodio - que ella misma rescata del olvido- sirve para poner en escena el conflicto suscitado entre vanguardia estética e ideología revolucionaria en la Argentina de comienzos de los años setenta: los films que los vanguardistas porteños llevaron al acto político en Santa Fe fueron recibidos como una provocación y todo terminó en escándalo.

Las preguntas que planteaban esas películas eran simples:

¿Cómo convertir las imágenes del cine en actos de la política sin que dejen de ser, al mismo tiempo, imágenes del cine?, ¿cómo intervenir en el campo político sin resignar la especificidad del discurso cinematográfico?, ¿cómo realizar una acción cultural que no pierda su identidad y que, al mismo tiempo, sea una práctica política? (Sarlo, "La noche" 252)

La hipótesis de Sarlo es que esos films vanguardistas todavía pretendían mantener imbricadas (en tensión, pero imbricadas) dos lógicas que, bajo el impulso de radicalización de la época, se separarían cada vez más hasta volverse refractarias.

\section{Historia y memoria}

En Historia(s) del cine, se repite un cartel que cita el título del libro de Bergson: materia y memoria. Ese sintagma condensa gran parte del proyecto de Godard. En definitiva, ¿̇cuál es la memoria material de las imágenes? Esa huella es lo que el cine siempre supo, aunque luego olvidó y es lo que ahora el film trae a la superficie gracias a esa mayéutica audiovisual formada por el montaje, la sobreimpresión y el fundido encadenado. En Lanzmann, como en Godard, las imágenes tienen memoria. Aunque los límites de lo que ellas pueden mostrar para recordar ese pasado son muy diferentes en uno y en otro realizador. Al igual que Historia(s) del cine, Shoab es un film sobre la memoria y la historia; pero mientras que en Godard las imágenes son puestas a recordar, en Lanzmann el recuerdo no tiene imagen, sino que está hecho de relatos. ${ }^{5}$

Sarlo escribe un texto fundamental sobre Shoah bajo el impacto que le produjo la proyección en la Cinemateca de la Sociedad Hebraica Argentina (SHA). ¿Cómo capturar eso que se resiste a la comprensión? Lanzmann "filma deshechos con la idea que de la insistencia sobre estos restos de una arqueología fúnebre puede extraerse un sentido" (Sarlo, "La historia" 11). En efecto: como un explorador, el cineasta descifra las huellas, lee eso que ha quedado entre los pliegues, analiza lo que se ha inscripto en el paisaje. Su film saca a la luz todo lo que la historia reciente ha preferido enterrar. El interrogante que el exterminio plantea al cine es, en efecto, ¿cómo exhibir eso que resulta inconcebible hasta la abstracción con un medio que parece condenado a lo concreto, a los detalles y a la superficie de las cosas? ¿Cómo hacer ver lo que no se 
puede mostrar? Lanzmann no utiliza imágenes de archivo: no exhibe las pruebas documentales de eso que ya no puede verse, sino que trabaja, justamente, sobre la incapacidad de la imagen para mostrar. No es el poder afirmativo de lo visual lo que le interesa, sino su debilidad, su insuficiencia, su tartamudeo. Aunque Shoah posee una extensión desmesurada, la estrategia de Lanzmann es minimalista: se reduce a mostrar unos paisajes serenos (donde cuesta reconocer la antigua fisonomía de los campos de concentración) y a registrar el testimonio de los sobrevivientes, los guardias de los campos o los campesinos que veían llegar los trenes cargados de prisioneros. Este complejo entramado de voces procura contrarrestar, con datos concretos y precisos, lo que se sabe de manera general o abstracta sobre la Solución Final. El relato construye, con infinita paciencia, una enciclopedia monstruosa que recorre las pequeñas tecnologías del horror. $\mathrm{Si}$ - como sostiene el célebre historiador Raul Hilberg - el único aporte del nazismo a la historia del mal fue la invención de una maquinaria burocrática para la muerte, Lanzmann se concentra en revelar esa logística administrativa sórdida y miserable que hizo posible el holocausto.

En esos mismos campos de concentración, donde el delegado del Comité Internacional de la Cruz Roja declaró no haber visto nada fuera de lo común, Lanzmann lee entre líneas. Todo consiste en formular las preguntas adecuadas. Y en querer ver. Es necesario mostrar la escritura invisible del horror, hacerla evidente, trazar un contorno alrededor de lo monstruoso que permita verlo y medirlo. Cuantificarlo. En definitiva, ¿Cómo se hace para planificar y administrar toda esa muerte? ¿Es posible matar 15\#00, 18\#00, $20 \# 00$ personas por día? Lanzmann traduce ese horror aparentemente sobrenatural a términos miserablemente burocráticos. Demuestra que eso que parece impensable pudo ser pensado. Por eso, a veces, sus preguntas parecen extrañas, incluso poco sustanciales. Alguien dice: "Encontré a mi amigo Carl entre la gente y me dijo que habían gaseado a su madre, a su padre y a su hermano". Sin embargo, Lanzman no parece interesado en esa escena terrible, sino que desvía su interrogatorio hacia otro lado: “¿Cuánto tiempo después de llegar al campo fue este encuentro entre tú y Carl?". Sus preocupaciones no se dirigen hacia los grandes temas, sino hacia los detalles, a veces técnicos, a veces nimios, siempre prácticos, concretos y cotidianos. ¿Cuántas personas podía llevar un tren hacia los campos? ¿Qué pasaba si se excedía ese número y las cámaras de gas no daban abasto? ¿Cuál era el corte de pelo que se les hacía antes de entrar a las cámaras de gas? ¿Cómo se coordinaban los turnos en los hornos crematorios? ¿Cómo se mitigaba el olor nauseabundo de los cadáveres en verano? ¿Qué tamaño debía tener la rejilla de las cámaras para poder evacuar rápidamente los fluidos corporales?

Sarlo advierte que ese culto del detalle supone, también, un riesgo; pero Lanzmann logra sortear el peligro de la mera acumulación porque no le interesa cada caso particular más que por su contribución a ese siniestro rompecabezas del exterminio. "No estamos hablando de usted — le dice al ex guarda SS — sino de Treblinka. Y su testimonio es capital para entender qué era el campo de exterminio". Este es el punto: recordar para entender. En la estela de Susan Sontag, Sarlo sostiene que "es más importante entender que recordar, aunque para entender sea preciso, también, recordar” ( Tiempo pasado 26). ${ }^{6}$ El libro Tiempo pasado se propone discutir la categoría de testimonio como forma privilegiada para reconstruir los sucesos pretéritos. ¿ Pero qué puede hacer la experiencia sin la reflexión? La capacidad de argumentar a partir de lo vivido es, sin duda, el mérito de textos como "La bemba", de Emilio de Ípola, o Poder y desaparición: los campos de concentración en Argentina, de Pilar Calveiro. En cambio, Sarlo cuestiona el film Los rubios por su despliegue subjetivista:

Carri no busca las "razones" de sus padres, ni mucho menos la traducción de esas "razones" por los testigos a quienes recurre; busca a sus padres en la abstracción de una vida cotidiana irrecuperable, y por eso no puede concentrarse en los motivos que los llevaron a la militancia política y a la muerte. (Tiempo pasado $147-148)^{7}$

A Lanzmann, en cambio, no le interesan los individuos, sino sus testimonios: igual que Agamben, considera que los sobrevivientes deben recordar en reemplazo de quienes serían los verdaderos testigos, aquellos que no pueden testificar porque han muerto. Esta es la razón por la cual resulta despiadado con todos sus entrevistados, sin diferenciar entre la condición de victimarios y de víctimas. Muchas de sus decisiones pueden resultar cuestionables (¿debería haber interrumpido la filmación cuando un sobreviviente se quiebra y dice que 
ya no quiere seguir recordando?, ¿debería haber prescindido de la cámara oculta para registrar el testimonio de un ex guarda SS?), pero nunca cede a la tentación del espectáculo.

Shoab es lo opuesto de films como La lista de Schindler o La vida es bella, que no se plantean ninguna pregunta y que solo piensan en el holocausto como excusa para una historia emotiva y conmovedora. Los espectadores de Benigni y de Spielberg son engañados (se dejan engañar) por la ilusión de que todo eso sucedió en otro momento y en otro sitio. No los toca. Según Sarlo, el film de Benigni es una mera distracción: el simulacro montado por el padre es tan eficaz que logra borrar la realidad terrible del campo de prisioneros y convierte el exterminio en un mundo de pura ficción. Como si nada de eso hubiera existido. Y lo cierto es que no hay nada allí que remita a una discusión sobre los vínculos entre arte, historia y política. ${ }^{8}$ Por su parte, la película de Spielberg invita a la crítica a releer Los pichiciegos. En la novela de Fogwill, los pichis no están unidos por una identidad compartida, sino por la necesidad de sobrevivir: "Paradójicamente, es la guerra la que ha destruido, para ellos, toda idea de nación; llegados a Malvinas como soldados de un ejército nacional, las operaciones de ese ejército han deteriorado todos los lazos de nacionalidad" (Sarlo, "No olvidar" 12). Los pichis constituyen una comunidad práctica cuyos lazos simbólicos son muy tenues. Hay ahí una forma particular de la verdad que la novela produce sobre la guerra de Malvinas. Pero, justamente, no debería ser ese el caso de los judíos de la película de Spielberg que "son parte de una comunidad simbólica a la que Schindler organiza en una comunidad práctica. Para hacerlo, tiene que pasar por alto la densidad simbólica del mundo de donde provienen sus protegidos" (Sarlo, "No olvidar" 15). Los judíos de Spielberg son víctimas abstractas y su film no hace otra cosa que olvidar el holocausto allí donde simula rememorarlo. Si Sarlo puede incorporar Los pichiciegos al debate es porque, a diferencia de Spielberg y al igual que Lanzmann, Fogwill descubre una forma de relato específica que remite a una lógica particular de los hechos.

En definitiva, se trata de indagar sobre las posibilidades del cine para producir conocimiento. ${ }^{9}$ Ese conocimiento es el único antídoto contra el olvido.

Sobre el holocausto - afirma Sarlo-, nunca puede saberse todo y, tampoco, nunca podrá resignarse a un saber parcial que
es a la vez inevitable (como el de toda práctica) y enemigo de la memoria. En cuanto se acepte "saber menos" se aceptará la
posibilidad de olvidar. Y, si se acepta la posibilidad de olvidar, lo siguiente no es la repetición (puede o no serlo) sino el acto
de resignar los valores que el holocausto destruyó junto con la destrucción de los judíos. Volver a la cuestión no es, entonces,
una actividad meramente del recuerdo fáctico, sino del recuerdo de las razones de la condena. Los detalles pelean por la
presentificación del pasado para hacer presentes los valores que en ese pasado fueron afectados por unos y defendidos por
otros. En este sentido, Shoah no intenta un movimiento solo reconstructivo, sino prospectivo. No dice esto se hizo, sino esto
pudo (y puede) ser hecho. (Sarlo, "La historia" 13)

Lanzmann interroga la memoria, pero desde un saber del presente. Esa es la intervención crítica que promueve la mirada del cineasta. La memoria no es el pasado: es la construcción de un saber con los materiales del pasado y la perspectiva del presente.

\section{El arte del presente}

En "Intelectuales", el capítulo final de Escenas de la vida posmoderna, Sarlo reflexiona sobre los intelectuales en el mundo contemporáneo. Indudablemente, cierta figura moderna del intelectual como profeta o como mentor o como guía ha entrado en el ocaso, pero hay una función crítica que es preciso conservar más allá de los cambios. ¿Cómo nombrar las diferentes manifestaciones culturales sin caer en la celebración populista o el prejuicio elitista? No se trata de un regreso al pasado, sino de una convocatoria para (re)construir ese lugar imprescindible de interrogación y de intervención según nuevos parámetros. En su momento, este texto suscitó diversas críticas. Horacio González, por ejemplo, cuestionó esa búsqueda de una justa distancia entre intelectuales y sociedad porque conducía a una disolución de las "asperezas y disonancias" en beneficio de un reformismo conciliador; para Andrea Pagni y Erna von der Walde, en cambio, Escenas de la vida posmoderna 
exhibía una postura nostálgica que extrañaba el lugar privilegiado que los intelectuales ya habían perdido para siempre. ${ }^{11}$ Sarlo responde a los cuestionamientos en "Retomar el debate". Sostiene allí, por un lado, que son necesarias las instituciones para que puedan tener lugar las transgresiones y, por otro lado, que "es nostálgico quien busca reconducir las condiciones presentes a las del pasado" (Sarlo, Tiempo presente 226). No es ese su caso, ya que sus reflexiones van y vienen entre dimensiones temporales, pero nunca pretenden instalarse en un mundo pretérito. Así como es necesario tomar distancia del pasado porque de lo contrario sería imposible avanzar, resulta imprescindible no enterrarlo en el olvido porque nos hundiríamos con él. ${ }^{12}$

El pasado no se olvida cuando se lo proyecta sobre el presente. Por eso, el ensayo a propósito de Shoah nunca se plantea como un análisis abstracto sobre algo que sucedió en otro tiempo y en otro lugar. O, más bien: Sarlo advierte que es preciso entender minuciosamente esa experiencia porque ella habla de nosotros y de nuestro mundo contemporáneo. De manera privilegiada, el cine permite conjugar la memoria en tiempo presente. Espectadora del film de Lanzmann en el contexto de los indultos de Menem, Sarlo no confunde los fenómenos, aunque establece las conexiones imprescindibles. Aprende la lección de Shoab: la relación entre las pruebas materiales y los valores es siempre inevitablemente tensa. Pero "el indulto desprecia esas pruebas y afecta los valores a partir de los cuales hombres y mujeres se consagraron y probablemente seguirán consagrándose a recogerlas; la igualación amnésica de la historia es, entre otras cosas, una ofensa al presente" (Sarlo, "La historia" 13). ${ }^{13}$ Siempre se ven los films de manera interesada. ¿Qué es lo que reconocemos en ellos de nuestra propia historia? Vemos para intentar recordar (defectuosamente, a destiempo, con culpa y con vergüenza) eso que nunca vimos.

El cine sirve para eso: para reinstalar las imágenes en el presente. Godard afirma que toda película de ficción es, a la vez, un documental sobre el momento de su rodaje; pero también es cierto que — para los ojos sagaces de un espectador atento- toda película del pasado se convierte en un testimonio sobre el momento en que es recibida. Hay, en Sarlo, un gusto por la écfrasis: para hablar de Akerman o de Raya Martin o de Sokúrov, siente la necesidad de describir el film como si lo estuviera viendo. Nos lo da a ver. No es solo una interpretación, es una experiencia de la visión. Entonces, con cada nueva lectura, el film vuelve a sintonizar con el presente. Como sostiene Daney:

Ciertamente, no estamos obligados a creer en lo que vemos — incluso es peligroso-, pero tampoco estamos obligados a tener fe en el cine. Debe haber riesgo y virtud - en una palabra, valor - en el hecho de mostrarle algo a alguien capaz de mirar lo que se le muestra. ¿De qué serviría enseñarle a alguien a leer lo visual y a decodificar los mensajes si no persiste, aunque sea mínimamente, la más arraigada de las convicciones: que ver es siempre superior a no ver? Y que lo que no se vio en el momento justo no se verá jamás. El cine es el arte del presente. Y, si la nostalgia no le sienta para nada, es porque la melancolía es su reverso inmediato. (Daney, Perseverancia 39) ${ }^{14}$

Para Sarlo, ese presente único del cine (su aquí y ahora) no tiene ninguna relación con lo efímero, sino, al contrario, con una experiencia aurática. En un bello texto sobre la cinefilia, Sarlo descubre en la sala Leopoldo Lugones la síntesis de "una forma recesiva" de ver cine:

No es la presencia real, la manifestación de algo único, lo sabemos. Es una copia de un film. Pero la visión transcurre en un tiempo que no controlo, como no lo controlo en la audición musical en vivo o el teatro. Esta imposibilidad del control restituye una densidad perdida para siempre por el desvanecimiento del aura y también por el fluir de la mercancía. Decido estar en esa sala; por esa decisión, en un punto, fugazmente detengo ese fluir y lo constituyo en ahora y aquí, no en cualquier momento ni de cualquier modo. La sala cinematográfica es la escena de un acontecimiento sobre el que no puedo introducir modificaciones: me obliga tanto como responde al deseo que me ha llevado allí. ("En busca del aura" 116)

Ingmar Bergman, Ozu, Ford, Rivette, Bruno Dumont, Fellini, Syberberg, Kitano, Kluge, Godard, Rossellini, Dreyer, Straub-Huillet: la lista de películas que ha visto en la Lugones (y en el Instituto Goethe o en el SHA, en el Anthology Film Archives de Manhattan o en el Babylon de Berlín) es tan extensa como heterogénea. ¿Qué es lo que tienen en común? Cada una de ellas ocupa una habitación distinta, pero todas esas 
habitaciones pertenecen al mismo edificio. Allí es posible plantear todas las discusiones sobre arte e ideología. Para la cultura audiovisual de mercado, en cambio, esas discusiones resultan completamente ajenas.

¿Por qué grandes cineastas como Ford y Ozu podían ocupar el centro de la industria cultural? ¿Por qué Cantando bajo la lluvia está tan lejos de Fiebre de sábado por la noche? (Sarlo, Escenas 134-135). ${ }^{15}$ Hay allí una experiencia de la visión que resulta impertinente a propósito de la TV o del cine mainstream (que, finalmente, posee más vínculos con el entretenimiento televisivo que con una dimensión auténticamente cinematográfica). Esto no supone una falta de interés por las nuevas tecnologías, pero cuando escribe sobre ciberespacio, sobre medios masivos o sobre videojuegos, Sarlo hace sociología de la cultura (le interesa el análisis del fenómeno y de sus efectos sociales). No le preocupa librar allí una discusión estética. Por supuesto que se aproxima a esa orilla de las videoculturas con las herramientas aprendidas en la literatura. Y también con lo que sabe a partir del cine. Es posible describir las operaciones del discurso comunicacional, pero eso no es más que una mezcla vulgarizada de materiales reciclados; es posible reflexionar sobre los medios masivos, pero no hay en ellos una base sobre la cual constituir una estética audiovisual; es posible estudiar el mensaje televisivo, pero no se puede amar la televisión. ¿Cómo intentar razonar con un medio que se resiste a abandonar la superficialidad más chata? Solo radicalizando la perspectiva del idiota (o sea, arrasando por completo con cualquier rasgo de pensamiento) se podría poner en cuestión ese reino absoluto de la banalidad. Finalmente, todo acaba en el insulto. Dicho de otra manera: para hacer la crítica de MTV, hay que volverse un poco Beavis y Butt-Head. ${ }^{16}$ De nuevo Daney: "Los grandes cineastas son forzosamente moralistas allí donde la TV, en el mejor de los casos, se plantea problemas de deontología” ( Cine, arte del presente 264).

En 1985, Sarlo ve a Susan Sontag en un cine de Nueva York donde proyectan las quince horas de Berlín Alexanderplatz de Fassbinder. Que sea Fassbinder y que sean quince horas no son datos accidentales. Como quería Tinianov, la duración es una forma. En esa escena se materializa una cierta ética del espectador. Porque la norteamericana ha sido para ella, desde siempre, un modelo de intelectual crítico. ${ }^{17} \mathrm{Y}$ así como dice que Sontag figura entre los mejores ensayistas de las últimas décadas, habría que agregar el nombre de la propia Sarlo a esa lista selecta. Es que, como Susan Sontag, ella también puede desplazarse entre la defensa de la alta cultura y la sensibilidad para lo actual ("esa cualidad que le permite situarse de modo estrictamente contemporáneo al presente y no por eso sucumbir al esnobismo de la novedad" [Sarlo, "La partida de Susan Sontag" 1]), sin concesiones y sin elitismo. Entre la cultura popular y la cultura de masas, entre el arte y la industria cultural, entre la memoria y el olvido, entre lo fugaz y lo imperecedero: en ese clivaje, el cine deviene un sendero privilegiado para acceder a las zonas más dinámicas, más conflictivas, más intensas del presente.

¿Qué le ofrece el cine a una crítica literaria? En sus primeros textos Sarlo se interesa por el vínculo entre cine e ideología, así como luego se obsesionará con el vínculo entre cine y memoria. Pero lo que aparece siempre bajo distintas formas es la dimensión de la historia, la sociedad y la política. Sus hipótesis sobre el cine constituyen reflexiones específicas y autónomas, pero esa especificidad y esa autonomía no resultan disyuntivas, sino que contribuyen — como una caja de resonancia - a amplificar su pensamiento literario y a proyectarlo como una interpretación política de la cultura.

\section{Referencias}

Aprile. Dirigida por Nanni Moretti, Sacher Film Rome, Bac Films, Canal+ y Radiotelevisione Italiana (RAI), 1998. Autohystoria. Dirigida por Raya Martin, 2007.

Beceyro, Raúl, et al. “Cine documental: la primera persona”. Punto de vista, n. ${ }^{\circ}$ 82, agosto de 2005, pp. 27-36.

Berlin Alexanderplatz.Berlin Alexanderplatz]. Dirigida por Rainer Fassbinder, Westdeutscher Rundfunk, Bavaria Film y RAI, 1980.

Boquitas pintadas. Dirigida por Leopoldo Torre Nilsson, 1974.

Calveiro, Pilar. Poder y representación: los campos de concentración en Argentina. Colihue, 2004. 
Cantando bajo la lluvia .Singin' in the Rain]. Dirigida por Stanley Donen y Gene Kelly, Metro-Goldwyn-Mayer, 1952. D’Est. Dirigida por Chantal Akerman, La Sept-Arte, Lieurac Productions, Paradise Films, Radiotelevisão Portuguesa y RTBF (Télévision Belge), 1993.

Daney, Serge. "El amante o la ignorancia del cine". Punto de vista, n. ${ }^{\circ} 44$, noviembre de 1992, pp. 24-26.

---. Cine, arte del presente. Santiago Arcos Editor, 2004.

---. Perseverancia. Reflexiones sobre el cine. Ediciones El Amante, 1998.

De Ípola, Emilio. "La bemba". La bemba. Acerca del humor carcelario y otros ensayos. Siglo XXI, 2005, pp. 15-60.

Didi-Huberman, Georges. Imágenes pese a todo. Memoria visual del Holocausto. Paidós, 2004.

El mercader de las cuatro estaciones. Händler der vier Jahreszeiten]. Dirigida por Rainer Fassbinder, Tango-Film, 1972. Fiebre de sábado por la noche. Saturday Night Fever]. Dirigida por John Badham, Paramount Pictures, 1977.

Fogwill, Rodolfo. Los pichiciegos. El Ateneo, 1983.

Francofonia.Francofonia]. Dirigida por Alexander Sokúrov, Idéale Audience y Museo de Louvre, 2015.

González, Horacio. "Perspectivas de la crítica cultural. Sobre Escenas de la vida posmoderna de Beatriz Sarlo". Espacios, n. ${ }^{\circ} 16$, julio-agosto de 1995, pp. 49-51.

Historia(s) del cine .Histoire(s) du cinéma]. Dirigida por Jean-Luc Godard, Canal +, Centre National de la Cinématographie, France 3, Gaumont, La Sept, Télévision Suisse Romande y Vega Films, 1989-1999.

Juan Moreira. Dirigida por Leonardo Favio, Centauro Films, 1973.

Julia. Digirida por Fred Zinnemann, 20th Century Studios, 1977.

L. F. [seudónimo de Beatriz Sarlo]. “Julia y Lilian Hellman”. Punto de Vista, n. ${ }^{\circ}$ 2, mayo de 1978, pp. 28-29.

La angustia corroe el alma .Angst essen Seele auf]. Dirigida por Rainer Fassbinder, Tango-Film, 1974.

La hora de los hornos. Dirigida por Fernando Solanas y Octavio Getino, 1968.

La lista de Schindler.Schindler's List]. Dirigida por Steven Spielberg, Amblin Entertainment, 1993.

La Mary. Dirigida por Daniel Tinayre, Globus Baires, 1974.

La Patagonia rebelde. Dirigida por Héctor Olivera, Aries Cinematográfica Argentina, 1974.

La tregua. Dirigida por Sergio Renán, Tamames-Zemborain, 1974.

La vida es bella .La vita è bella]. Dirigida por Roberto Benigni, Melampo Cinematografica, Cecchi Gori Group y Miramax, 1998.

Las amargas lágrimas de Petra von Kant.Die bitteren Tränen der Petra von Kan]. Dirigida por Rainer Fassbinder, Filverlag der Autoren-Tango-Film, 1972.

Los rubios. Dirigida por Albertina Carri, 2003.

Los siete locos. Dirigida por Leopoldo Torre Nilsson, Producciones Cinematográficas Litoral S. A. C. I. F. I., 1973.

Nazareno Cruz y el lobo. Dirigida por Leonardo Favio, Choila Producciones Cinematográficas, 1975.

Niccolini, Silvia [seudónimo de Beatriz Sarlo]. “CCómo leer literatura? Algunas consideraciones sobre el formalismo norteamericano". Punto de Vista, n. ${ }^{\circ} 2$, mayo de 1978, pp. 3-5.

---. "Fassbinder: por un cine de ideas". Punto de Vista, n. ${ }^{\circ}$, julio de 1978, pp. 29-31.

Noche y niebla. Nuit et brouillard]. Alain Resnais, 1956.

Padre padrone. Dirigida por Paolo y Vittorio Taviani, Cinema S. r. I, 1977.

Pagni, Andrea y Erna von der Walde. "Qué intelectuales en tiempos posmodernos o de 'cómo ser radical sin ser fundamentalista'. Aportes para una discusión con Beatriz Sarlo". Culturas del Rio de la Plata (1973-1995): transgresión e intercambio, editado por Roland Spiller, Vervuert, 1995, pp. 287-312.

Podlubne, Judith. "Beatriz Sarlo / Horacio González: Perspectivas de la crítica cultural”. Las operaciones de la crítica, editado por Alberto Giordano y María Celia Vásquez, Beatriz Viterbo Editora, 1998, pp. 67-78.

"Punto de vista señala". Punto de Vista, n. ${ }^{\circ}$, mayo de 1978, pp. 27-28.

Quebracho. Dirigida por Ricardo Wullicher, Talar Films, 1974. 
Relatos salvajes. Dirigida por Damián Szifron, Kramer \& Sigma Films, El Deseo, Telefe y Corner Contenidos, 2014.

Richard, Nelly. "Un debate latinoamericano sobre práctica intelectual y discurso crítico". Revista Iberoamericana, vol. 68, n. ${ }^{\circ} 200$, julio-septiembre de 2002, pp. 897-906.

Route 181. Dirigida por Eyal Sivan y Michel Khleifi, Momento!, Sindibad Films, Sourat Films y Westdeutscher Rundfunk (WDR), 2004.

Sarlo, Beatriz. "Cine argentino: de Juan Moreira a La tregua". Los Libros, n. ${ }^{\circ} 39$, enero-febrero de 1975, pp. 11-14.

---. "En busca del aura". Revista de Cine, n. ${ }^{0}$ 1, 2014, pp. 111-116.

---. Escenas de la vida posmoderna. Intelectuales, arte y videocultura en la Argentina. Ariel, 1994.

---. Ficciones argentinas. Mardulce, 2012.

---. "Francofonia. La compleja alma rusa". Revista de Cine, n. ${ }^{\circ}$ 3, 2016, pp. 117-120.

--.. "Imágenes". Punto de Vista, n. ${ }^{\circ}$ 60, abril de 1998, pp. $42-46$.

---. Instantáneas. Medios, ciudad y costumbres en el fin de siglo. Ariel, 1996.

--.. "Intelectuales: jarcaicos o marginales? Situación de los intelectuales en el fin de siglo". Punto de Vista, n. 47 , diciembre de 1993, pp. 1-6.

--- “Intelectuales: ¿escisión o mimesis?”. Punto de Vista, n. ${ }^{\circ}$ 25, diciembre de 1985, pp. 1-6.

---. "La diatriba". Punto de Vista, n. ${ }^{\circ} 79$, agosto de 2004, pp. 35-36.

---. "La historia contra el olvido". Punto de Vista, n. ${ }^{\circ} 36$, diciembre de 1989, pp. 11-13.

---. "La imaginación del futuro". Punto de Vista, n. ${ }^{\circ}$ 38, octubre de 1990, pp. 15-17.

---. "La noche de las cámaras despiertas". La máquina cultural. Maestras, traductores y vanguardistas. Ariel, 1998, pp. 195-269.

--.. "La originalidad de las Histoire(s) du cinéma". Jean-Luc Godard: el pensamiento del cine. Cuatro miradas sobre Histoire(s) du cinéma, editado por David Oubiña, Paidós, 2003, pp. 25-43.

---. "La partida de Susan Sontag". Punto de Vista, n. ${ }^{\circ} 81$, abril de 2005, p. 1.

--.. "No olvidar la guerra de Malvinas. Sobre cine, literatura e historia". Punto de Vista, n. ${ }^{\circ}$ 49, agosto de 1994, pp. 11-15.

---. "Roland Barthes: una biografía imposible". El mundo de Roland Barthes, editado por Beatriz Sarlo, Centro Editor de América Latina, 1981, pp. 21-42.

---. “Sobre Nazareno Cruz y el lobo". Los Libros, n. " 41, mayo-junio de 1975, pp. 24-25.

--.. "Sontag en un cine”. Plan de operaciones. Ediciones Universidad Diego Portales, 2013, pp. 119-122.

---. Tiempo pasado: cultura de la memoria y giro subjetivo. Una discusión. Siglo XXI, 2005.

---. Tiempo presente. Notas sobre el cambio de una cultura. Siglo XXI, 2001.

---. "Un cine catártico". Revista de Cine, n. ${ }^{\circ}$ 2, 2016, pp. 15-17.

--. "Un cine conceptual". Punto de Vista, n. ${ }^{\circ} 88$, agosto de 2007, pp. 37-38.

---. "Un escrito irresponsable”. El guion cinematográfico, editado por David Oubiña y Gonzalo Aguilar, Paidós / Universidad del cine, 1997, pp. 135-141.

Saxton, Libby. “Anamnesis and Bearing Witness: Godard / Lanzmann”. For Ever Godard, editado por Michael Temple et al., Black Dog Publishing, 2004, pp. 364-379.

Shoah. Dirigida por Claude Lanzmann, 1985.

Solo quiero que me amen.Ich will doch nur, daßibr mich liebt]. Dirigida por Rainer Fassbinder, Bavaria Atelier GmbH, 1976.

\section{Notas}

* Artículo de investigación.

1 Sobre estos films, véanse dos escritos de Sarlo "Un cine catártico" y Tiempo pasado: cultura de la memoria y giro subjetivo (146-151). Sobre los escritores contemporáneos, véase Ficciones argentinas, también de Sarlo. 
Para Sarlo, en el film de Solanas hay muchos problemas mal resueltos: "Exageración del peso de la contradicción capital/ interior, la marginalidad como eje político, debilidad relativa de la presencia obrera en el material filmado y recopilado". Asimismo, presenta una "versión no articulada sino yuxtaposicional de la historia y la realidad argentinas" y "como instrumento pedagógico, es relativamente pobre" "Cine argentino" 11).

3 El artículo insiste sobre la necesaria resistencia de los intelectuales frente al fascismo, sobre los vergonzosos tribunales de actividades antinorteamericanas, sobre el valor de la ira frente a las injusticias y sobre las delaciones. Sarlo concluye con una célebre cita de las memorias de Hellman: "La verdad lo convertía a uno en traidor, como a menudo sucede en tiempo de canallas" (“Julia y Lillian Hellman" 29).

4 Sobre Barthes y Brecht, véase un texto contemporáneo: "Roland Barthes: una biografía imposible" (Sarlo). Lo que le interesa a Sarlo en Fassbinder es esa articulación entre la forma y las condiciones sociohistóricas. Y, por eso mismo, cuestiona ciertos límites en el formalismo norteamericano (Wayne Booth), que tiende a funcionar de manera abstracta, soslayando esa inflexión (véase Niccolini [seudónimo de Sarlo], “¿Cómo leer literatura?”).

5 Lanzmann renuncia al archivo, porque afirma que "las imágenes reales son falsas", son "imágenes sin imaginación” (citado en Didi-Huberman 143). No hay archivos y no puede haberlos. El exterminio también fue eso. Por ese motivo, el holocausto no debe mostrarse. Las imágenes siempre filtran el horror y, por el solo hecho de ser imágenes -aún las imágenes más horrorosas-, nos protegen de él. Hacen que resulte más tolerable. Para Godard, el problema del cine es que no supo mostrar los campos de exterminio. Todas las imágenes del cine cargan con ese fracaso y aluden a él. Por eso la función del montaje, en Historia(s) del cine, consiste en forzar los planos para extraer de ellos eso que no se vio en su momento. Sobre la polémica Lanzmann-Godard, véanse Didi-Huberman y Saxton.

6 El riesgo es la proliferación del detalle individual, porque "cierra ilusoriamente las grietas de la intriga y la presenta como si esta pudiera o debiera representar un todo" (Sarlo, Tiempo pasado 70). Shoah escapa a ese peligro porque el detalle es allí lo que no conocíamos; sin embargo, la acumulación de ejemplos puede volverse un problema en un film como Route 181, que tiene varios puntos de contacto con el documental de Lanzmann (Sarlo, "La diatriba").

7 En otra parte dice a propósito de ciertas narraciones testimoniales: "La subjetividad es histórica y si se cree posible volver a captarla en una narración, es su diferencialidad la que vale. Una utopía revolucionaria cargada de ideas recibe un trato injusto si se la presenta solo o fundamentalmente como drama posmoderno de los afectos" (Sarlo, Tiempo pasado 91).

8 Sobre La vida es bella, véase "La familia de las víctimas" (Sarlo, Tiempo presente). A la película de Benigni se le opone Aprile: "Este film es el más político de los films políticos porque presenta una relación inquebrantable entre la esfera pública y la esfera privada" (Sarlo, Tiempo presente 172). Sin embargo, más tarde Sarlo revisará su opinión sobre el film de Moretti: en una discusión sobre cine documental considera que, "peligrosamente, algunos momentos de Aprile se aproximan a la pornografía" porque Moretti insiste en una inscripción de su propio cuerpo sin una deliberación formal (Beceyro et al. 29).

9 En otra parte, Sarlo conecta a Lanzmann con Akerman, porque tanto Shoah como D'Est forman parte de un pequeño grupo de films que no ilustran lo que ya se sabe, sino que permiten que sepamos más (ya sea sobre el holocausto o sobre el postsocialismo). Véase Sarlo, "Imágenes".

10 A veces, el cine puede proponer "hipótesis estético-narrativas sobre el futuro". Ese es el caso de los films de Tarkovsky, que presentan una "memoria ficcional de lo que aún no ha sucedido" y, entonces, funcionan "como una advertencia moral" (Sarlo, "La imaginación" 16).

11 Para ver los cuestionamientos que se le han hecho Sarlo, véanse Pagni y von der Walde y González. En Podlubne y en Richard se reconstruyen los términos del debate.

12 Desde el retorno a la democracia, Sarlo venía reflexionando sobre estas cuestiones y, de alguna manera, ya había anticipado su postura en diversos artículos, como en "Intelectuales: ¿escisión o mimesis?" e "Intelectuales: ‘arcaicos o marginales?".

13 No se trata, por supuesto, de establecer un paralelismo elemental y esquemático (por lo tanto, falso) entre el Holocausto y la dictadura militar en la Argentina. Sarlo nunca cae en esa trampa tan habitual y, sin embargo, aprovecha ciertas continuidades básicas, ciertas resonancias siniestras que sirven para pensar el presente. Lo mismo sucede con Noche y niebla: "Aprendimos a escuchar en el film de Resnais algo que no estaba allí para nosotros cuando se proyectó por primera vez en la Argentina, hace más de treinta años" (Sarlo, Instantáneas 104-105).

14 Sarlo comparte con Daney una misma sensibilidad crítica. Y, de hecho, Punto de Vista publicó muy tempranamente la traducción al castellano de uno de sus artículos. Véase Daney, "El amante o la ignorancia del cine", y los otros textos sobre el crítico francés que aparecen en ese mismo número de la revista.

15 No se trata, por supuesto, de una celebración acrítica del género "cine culto" frente a la televisión popular. Sarlo discute, por ejemplo, las inconsistencias de Francofonia, pero, aún así, Sokúrov le interesa porque es posible plantear allí una discusión estética (véase Sarlo, "Francofonía").

16 En "Reyes del cool" hay un preciso análisis sobre Beavis y Butt-Head como críticos televisivos. Véase Sarlo, Instantáneas .

17 Sobre Sontag en Nueva York, véase Sarlo, "Sontag en un cine". Sobre Sontag como modelo del intelectual crítico, véase Sarlo, "La partida de Susan Sontag". 
Licencia Creative Commons CC BY 4.0

Cómo citar este artículo:: Oubiña, David. "Lectores y espectadores: Beatriz Sarlo crítica de cine”. Cuadernos de Literatura, vol. 24, 2020. https://doi.org/10.11144/Javeriana.cl24.lebc 